\title{
Evaluation of a Mathematical Model for Predicting the Relationship between Protein and Energy Intakes of Low-Birth-Weight Infants and the Rate and Composition of Weight Gain
}

\author{
SUDHA KASHYAP, KARL F. SCHULZE, RAJASEKHAR RAMAKRISHNAN, RALPH B. DELL, AND \\ WILLIAM C. HEIRD' \\ Department of Pediatrics, College of Physicians and Surgeons of Columbia University and Babies Hospital \\ (Presbyterian Hospital), New York. New York 10032
}

\begin{abstract}
A model for predicting the relationship between protein and energy intakes of low-birth-weight (LBW) infants and the rate and composition of weight gain is described. It is based on linear multiple regression equations summarizing the rates of weight gain, nitrogen retention, and energy retention of 101 previously studied LBW infants fed protein intakes ranging from 2.25 to 3.9 $\mathrm{g} \cdot \mathrm{kg}^{-1} \cdot \mathrm{d}^{-1}$ and concomitant energy intakes ranging from 115 to $147 \mathrm{kcal} \cdot \mathrm{kg}^{-1} \cdot \mathrm{d}^{-1}$ plus current theory concerning nutrient retention and body composition. To test the validity of the model, three combinations of protein and energy intake predicted by the model to result in specific rates and compositions of weight gain were fed to $44 \mathrm{LBW}$ infants, and the observed rates of weight gain, protein accretion, and fat accretion were compared with the rates predicted by the model. Differences in these and other outcome variables between two of the groups, the intakes of which differed only in energy, also were compared to provide additional insight into the effect of concomitant energy intake on protein utilization. Across groups, actual outcomes correlated closely with predicted outcomes, supporting the validity of the model for the total population. However, outcomes of individual infants deviated as much as $30 \%$ from predicted outcomes; the magnitude of the deviation was independent of birth weight, gestational age, or size for gestational age. In addition, the mean rate of protein accretion of the group fed the highest protein/ energy ratio was significantly less than predicted. The higher mean urinary nitrogen excretion as well as blood urea nitrogen and plasma amino acid concentrations of this group versus the group that received a similar protein intake with a higher energy intake suggest that the higher energy intake improved nitrogen utilization. In toto, the data support the concept that the rate and composition of weight gain of $\mathrm{LBW}$ infants can be manipulated by intake; however, for individual infants, the extent of manipulation seems to be dependent on as-yet-unidentified inherent biologic variables. (Pediatr Res 35: 704-712, 1994)
\end{abstract}

Received January 26, 1993; accepted January 26, 1994.

Correspondence and reprint requests: Sudha Kashyap, M.D., Department of Pediatrics, College of Physicians and Surgeons, Columbia University, 630 West 168th St., New York, NY 10032.

Supported by grants from the National Institutes of Health (HDI3020, HDI 3063, and RR00645) and Ross Laboratories.

Current address: Children's Nutrition Research Center, Department of Pediatrics, Baylor College of Medicine, Houston. TX 77030.
Abbreviations

LBW, low birth weight

Current guidelines for feeding LBW infants stress the importance of achieving as soon after birth as possible a rate of weight gain that is at least equal to or, preferably, greater than the intrauterine rate $(1,2)$. A number of studies have demonstrated that even the higher rates of weight gain can easily be achieved but that the accompanying rates of fat accretion are as much as 3 -fold greater than the intrauterine rate (3-8). The desirability of such high rates of fat accretion are unknown. For most populations, they are considered undesirable, but this may not be true for the LBW infant who is born with limited fat stores. Moreover, approximately $40 \%$ of the weight gained by term infants over the first 4 mo of life appears to be fat (9), raising the possibility that high rates of fat accretion are unavoidable during early extrauterine life.

Our previous studies of growth and nutrient retention of LBW infants fed varying intakes of protein and energy (3, 10-13) suggest that postnatal rates of weight gain as well as protein and fat accretion are closely related to dietary protein and energy intakes. The data from these studies are summarized quite well by linear multiple regression equations relating the rate of weight gain primarily to the intakes of protein and energy and the rates of protein and fat accretion to dietary protein and energy intakes, respectively (14). We therefore hypothesized that these equations might be used as the basis of a model for predicting the relationship between dietary protein and energy intakes of LBW infants and the rate and composition of weight gain. We hypothesized further that demonstration of the validity of such a model would provide at least suggestive evidence that the rate and composition of weight gain of LBW infants can be manipulated sufficiently by diet to make a study of the short- and long-term effects of rate and composition of extrauterine weight gain feasible.

The development and validation of such a model are reported here. The primary goals of the investigation were to develop a model relating the rate and composition of weight gain of LBW infants to protein and energy intakes, use it to predict intakes likely to result in specific rates and compositions of weight gain as well as to predict the rates and compositions of weight gain expected in infants fed specific protein and energy intakes, and test it by determining whether the outcomes expected with specific intakes were in fact achieved. Secondary goals were to determine the infant's metabolic and biochemical tolerance of the intakes fed and to obtain additional information concerning the effect of energy intake on protein utilization. 


\section{MATERIALS AND METHODS}

Development of the Model. Multiple regression equations. The model for predicting the relationship between protein and energy intakes of LBW infants and the rate and composition of weight gain is based on linear multiple regression equations summarizing the rates of weight gain and the rates of both nitrogen and energy retention observed in previous studies of $101 \mathrm{LBW}$ infants fed gross protein intakes ranging from 2.25 to $3.9 \mathrm{~g} \cdot \mathrm{kg}^{-1} \cdot \mathrm{d}^{-1}$ and concomitant gross energy intakes of 115 to $147 \mathrm{kcal} \cdot \mathrm{kg}^{-1} \cdot \mathrm{d}^{-1}$, both varied independently of the other $(3,10-14)$. The mean birth weight of these infants $( \pm$ SD) was $1431 \pm 220 \mathrm{~g}$; mean gestational age was $31.6 \pm 1.8 \mathrm{wk}$. Dependent variables tested for statistical significance in deriving these equations included protein and energy intake as well as birth weight, gestational age, and size for gestational age.

The multiple regression equation summarizing the rate of weight gain $(\Delta \mathrm{W})$ of these infants is as follows:

$$
\begin{aligned}
& \Delta \mathrm{W}=0.095 \mathrm{E}_{\mathrm{in}}+3.6 \mathrm{P}_{\mathrm{in}}-0.00468 \mathrm{BW}+1.699 \\
&\left(r^{2}=0.62 ; \text { residual error }=3.34 \mathrm{~g} \cdot \mathrm{kg}^{-1} \cdot \mathrm{d}^{-1}\right)
\end{aligned}
$$

In this and subsequent equations, $E_{\text {in }}$ is energy intake $\left(\mathrm{kcal} \cdot \mathrm{kg}^{-1}\right.$. $\left.\mathrm{d}^{-1}\right), P_{\text {in }}$ is protein intake $\left(\mathrm{g} \cdot \mathrm{kg}^{-1} \cdot \mathrm{d}^{-1}\right)$, and $\mathrm{BW}$ is birth weight $)$.

The equation summarizing the nitrogen retention $\left(\mathrm{N}_{\mathrm{s}}\right)$ of the 101 infants is as follows:

$$
\begin{aligned}
N_{\mathrm{s}}=0.712 \mathrm{~N}_{\text {in }}+0.0157 \\
\left(r^{2}=0.83 ; \text { residual error }=0.026 \mathrm{~g} \cdot \mathrm{kg}^{-1} \cdot \mathrm{d}^{-1}\right)
\end{aligned}
$$

where $\mathrm{N}_{\text {in }}$ is nitrogen intake.

The equation summarizing energy balance $\left(\mathrm{E}_{\mathrm{s}}\right)$, i.e. gross energy intake minus stool and urinary losses minus energy expenditure $\left(\mathrm{kcal} \cdot \mathrm{kg}^{-1} \cdot \mathrm{d}^{-1}\right)$, is as follows:

$$
\begin{aligned}
& E_{\mathrm{s}}=0.714 \mathrm{E}_{\mathrm{in}}-35.08 \\
&\left(r^{2}=0.72 ; \text { residual error }=6.25 \mathrm{kcal} \cdot \mathrm{kg}^{-1} \cdot \mathrm{d}^{-1}\right)
\end{aligned}
$$

Relationship between protein and fat accretion and intakes of protein and energy. According to current theory concerning nutrient retention and body composition, nitrogen accretion is assumed to represent storage of new protein. Thus, the equation summarizing the nitrogen retention data can be converted to one summarizing protein accretion $\left(\mathrm{P}_{\mathrm{s}}\right)$ by substituting $\mathrm{P}_{\mathrm{s}} / 6.25$ and $P_{\text {in }} / 6.25$ for $N_{s}$ and $N_{i n}$ :

$$
P_{\mathrm{s}}=0.712 \mathrm{P}_{\text {in }}+0.098
$$

Also according to current theory, the general relationship between energy balance and fat accretion $\left(F_{s}\right)$, ignoring the small amount of energy likely to be stored as carbohydrate $(15,16)$, is expressed as $F_{s}=\left(E_{s}-5.65 P_{s}\right) / 9.25$, where the constants 5.65 and 9.25 are heats of combustion $(\mathrm{kcal} / \mathrm{g})$ of protein and fat, respectively (17). Substituting equations 3 and 4 for energy balance $\left(E_{s}\right)$ and protein accretion $\left(P_{s}\right)$ into the general equation for fat accretion $\left(F_{s}\right)$ yields the following:

$$
F_{s}=0.077 E_{\text {in }}-0.435 P_{\text {in }}-3.85
$$

Relationship between protein and fat accretion. The next step in development of the model is to select the desired relationship between the rates of protein and fat accretion. Any arbitrary relationship, of course, could have been chosen; we chose the relationship during the interval of gestation during which the fetus increases from $1400 \mathrm{~g}$, the approximate average birth weight of infants enrolled in the studies giving rise to the multiple regression equations (and, hence, the average body weight when birth weight is regained), to $2200 \mathrm{~g}$, a reasonable "discharge weight." During this interval, the fetus adds $116 \mathrm{~g}$ of protein and $110 \mathrm{~g}$ of fat (18); thus, the ratio of protein accretion to fat accretion, $P_{s} / F_{s}$, is 1.055 .

Substituting equations 4 and 5 for $P_{s}$ and $F_{s}$ in the above ratio equation, i.e. $\mathrm{P}_{\mathrm{s}} / \mathrm{F}_{\mathrm{s}}=1.055$, and solving the equation for either protein intake or energy intake expresses the relationship between the intakes of these two nutrients likely to produce the desired relationship between the rates of accretion of protein and fat. Solving the equation for energy intake yields the following:

$$
E_{\text {in }}=14.42 P_{\text {in }}+51.2
$$

The final step is to substitute equation 6 into equation 1 summarizing the rate of weight gain:

$$
\begin{aligned}
\Delta W=0.095\left(14.42 P_{\text {in }}+51.2\right)+ & 3.6 P_{\text {in }} \\
& -0.00468 \mathrm{BW}+1.699
\end{aligned}
$$

or

$$
\Delta \mathrm{W}=4.97 \mathrm{P}_{\text {in }}-0.0468 \mathrm{BW}+6.563
$$

For the infant weighing $1400 \mathrm{~g}$ at birth, this equation becomes $\Delta W=4.97 P_{\text {in }}+0.011$. Either of these equations plus equation 6 can be used to predict the gross protein and energy intakes required to produce any desired rate of weight gain with the same composition as that of the fetus over a similar period of development.

Use of the Model. Over the weight range of interest, the rate of weight gain is well described by the exponential equation $\mathrm{W}_{\mathrm{t}}$ $=\mathrm{W}_{0} \mathrm{e}^{\mathrm{sW} \cdot \mathrm{T} / 1000}$, in which $\mathrm{W}_{\mathrm{t}}$ is weight at any time, $\mathrm{W}_{0}$ is the initial weight, $T$ is time in days required for $W_{0}$ to reach $W_{t}$, and 1000 converts $\Delta \mathrm{W}$ from $\mathrm{g} \cdot \mathrm{kg}^{-1} \cdot \mathrm{d}^{-1}$ to $\mathrm{kg} \cdot \mathrm{kg}^{-1} \cdot \mathrm{d}^{-1}$. At $\mathrm{W}_{\mathrm{t}}=$ $2200 \mathrm{~g}$ and $\mathrm{W}_{0}=1400 \mathrm{~g}, \Delta \mathrm{W}=1000 \ln (2200 / 1400) / \mathrm{T}$, or $\Delta \mathrm{W}$ $=452 / \mathrm{T}$.

On average, the $1400 \mathrm{~g}$ fetus increases to $2200 \mathrm{~g}$ in $34 \mathrm{~d}$. However, the infant who weighs $1400 \mathrm{~g}$ at birth, loses weight, regains birth weight at $2 \mathrm{wk}$ of age, and subsequently gains weight at the intrauterine rate will not reach $2200 \mathrm{~g}$ until $48 \mathrm{~d}$ of age. If it is desired to have the infant reach discharge weight $(2200 \mathrm{~g})$ a week sooner, thereby recouping a week of the 2 wk required to regain birth weight, a weight gain of $800 \mathrm{~g}$ must be achieved in $27 \mathrm{~d}$ rather than $34 \mathrm{~d}$. This will require a rate of weight gain of $16.7 \mathrm{~g} \cdot \mathrm{kg}^{-1} \cdot \mathrm{d}^{-1}$. Similarly, to achieve discharge weight $2 \mathrm{wk}$ sooner, i.e. to achieve complete catch-up growth, a weight gain of $800 \mathrm{~g}$ must be achieved in $20 \mathrm{~d}$. This necessitates a rate of weight gain of $22.6 \mathrm{~g} \cdot \mathrm{kg}^{-1} \cdot \mathrm{d}^{-1}$.

Substituting each of these rates of weight gain into equation 7 , solving the equation for $P_{\text {in }}$, and using the resulting value of $P_{\text {in }}$ to solve equation 6 for $E_{\text {in }}$ yields the protein and energy intakes that, theoretically, will result in the desired rates of weight gain with a protein:fat ratio of 1.055 . The intakes computed to result in a rate of weight gain of $16.7 \mathrm{~g} \cdot \mathrm{kg}^{-1} \cdot \mathrm{d}^{-1}$ are $3.36 \mathrm{~g} \cdot \mathrm{kg}^{-1} \cdot \mathrm{d}^{-1}$ protein and $99.6 \mathrm{kcal} \cdot \mathrm{kg}^{-1} \cdot \mathrm{d}^{-1}$ energy; those required to produce complete catch-up growth by the time of discharge, at a rate of weight gain of $22.6 \mathrm{~g} \cdot \mathrm{kg}^{-1} \cdot \mathrm{d}^{-1}$, are protein at $4.5 \mathrm{~g} \cdot \mathrm{kg}^{-1} \cdot \mathrm{d}^{-1}$ and energy at $116.8 \mathrm{kcal} \cdot \mathrm{kg}^{-1} \cdot \mathrm{d}^{-1}$. Obviously, the model also can be used to predict the protein and energy intakes likely to result in other rates and compositions of weight gain or, as described below, to predict rates of weight gain, protein accretion, and fat accretion expected with any combination of protein and energy intakes.

Table 1. Composition of the three experimental formulas*

\begin{tabular}{lrrc}
\hline \multicolumn{1}{c}{ Component } & Formula 1 & Formula 2 & Formula 3 \\
\hline Protein $(\mathrm{g} / \mathrm{L})$ & $18.2 \pm 0.6$ & $23.7 \pm 1.3$ & $23.2 \pm 1.3$ \\
Energy $(\mathrm{kcal} / \mathrm{L})$ & $539 \pm 4.5$ & $647 \pm 2.9$ & $792 \pm 10.4$ \\
Sodium $(\mathrm{mmol} / \mathrm{L})$ & $19.6 \pm 0.4$ & $19.1 \pm 0.5$ & $19.0 \pm 0.5$ \\
Potassium (mmol/L) & $21.9 \pm 0.5$ & $22.9 \pm 0.6$ & $23.7 \pm 0.6$ \\
Calcium (mmol/L) & $35.1 \pm 0.6$ & $34.6 \pm 1.0$ & $34.1 \pm 1.1$ \\
Magnesium (mmol/L) & $3.9 \pm 0.2$ & $3.8 \pm 0.3$ & $3.7 \pm 0.2$ \\
Chloride (mmol/L) & $15.9 \pm 0.7$ & $15.9 \pm 0.5$ & $15.6 \pm 0.8$ \\
Phosphorus (mmol/L) & $23.5 \pm 0.6$ & $24.1 \pm 0.5$ & $23.0 \pm 0.6$ \\
\hline
\end{tabular}

* Mean $( \pm S D)$ of nine analyses of each formula, three before beginning the study, three midway into the study, and three near the end of the study. 
Table 2. Clinical characteristics of the three study groups*

\begin{tabular}{|c|c|c|c|}
\hline & $\begin{array}{l}\text { Group 1 } \\
(n=14)\end{array}$ & $\begin{array}{l}\text { Group 2 } \\
(n=15)\end{array}$ & $\begin{array}{l}\text { Group } 3 \\
(n=15)\end{array}$ \\
\hline Birth weight (g) & $1309 \pm 267$ & $1343 \pm 256$ & $1325 \pm 235$ \\
\hline $750-1000 \mathrm{~g}(n)$ & 1 & 1 & 1 \\
\hline $1001-1250 \mathrm{~g}(n)$ & 4 & 4 & 4 \\
\hline $1251-1500 \mathrm{~g}(n)$ & 6 & 6 & 6 \\
\hline $1501-1750 \mathrm{~g}(n)$ & 3 & 4 & 4 \\
\hline Gestational age (wk) & $30.6 \pm 2.2$ & $30.7 \pm 2.1$ & $31.0 \pm 2.2$ \\
\hline$<30$ wk $(n)$ & 3 & 3 & 3 \\
\hline $30-32$ wk $(n)$ & 8 & 8 & 11 \\
\hline$>32 \mathrm{wk}(n)$ & 3 & 4 & 1 \\
\hline \multicolumn{4}{|l|}{ Size for gestational age $\dagger$} \\
\hline$<10$ th percentile $(n)$ & 1 & 1 & 3 \\
\hline 10th-25th percentile $(n)$ & 5 & 7 & 2 \\
\hline 25 th -50 th percentile $(n)$ & 5 & 3 & 7 \\
\hline 50 th-75th percentile $(n)$ & 3 & 4 & 3 \\
\hline Age, first feeding (d) & $4.4 \pm 3.0$ & $2.5 \pm 2.0$ & $3.5 \pm 3.3$ \\
\hline Age, full intake (d) & $17.4 \pm 6.6$ & $15.0 \pm 5.7$ & $18.5 \pm 8.2$ \\
\hline Age, BW regained (d) & $16.1 \pm 7.5$ & $14.0 \pm 4.3$ & $13.4 \pm 7.6$ \\
\hline Number with RDS & 11 & 12 & 12 \\
\hline Assisted ventilation & 4 & 4 & 4 \\
\hline CPAP & 11 & 12 & 12 \\
\hline Oxygen therapy & 10 & 8 & 8 \\
\hline Number with IVH & 7 & 4 & 3 \\
\hline Number who received antibiotics & 12 & 12 & 12 \\
\hline Number who received theophylline & 4 & 2 & 3 \\
\hline Number who received blood & 8 & 5 & 5 \\
\hline Number who received TPN & 13 & 10 & 11 \\
\hline Duration of TPN $(d \pm S D)$ & $9.8 \pm 5.6$ & $7.8 \pm 3.0$ & $12.2 \pm 7.0$ \\
\hline
\end{tabular}

* BW, birth weight; RDS, respiratory distress syndrome; CPAP, continuous positive airway pressure; IVH, intraventricular hemorrhage; TPN, total parenteral nutrition.

† Based on classification described by Battaglia and Lubchenko (28).

Evaluation of the Model. The original intent was to evaluate the model by determining whether infants fed the protein and energy intakes predicted by the model to result in partial $(3.4 \mathrm{~g}$. $\mathrm{kg}^{-1} \cdot \mathrm{d}^{-1}$ and $\left.100 \mathrm{kcal} \cdot \mathrm{kg}^{-1} \cdot \mathrm{d}^{-1}\right)$ and complete catch-up growth $\left(4.5 \mathrm{~g} \cdot \mathrm{kg}^{-1} \cdot \mathrm{d}^{-1}\right.$ and $\left.117 \mathrm{kcal} \cdot \mathrm{kg}^{-1} \cdot \mathrm{d}^{-1}\right)$ with the same composition as that during fetal development did, in fact, gain weight and store protein and fat at the expected rates. However, the protein content of the formulas manufactured for the study was less than intended. Based on the measured protein and energy contents of these formulas (Table 1) and an assumed intake of $180 \mathrm{~mL} \cdot \mathrm{kg}^{-1} \cdot \mathrm{d}^{-1}$, the mean gross protein and energy intakes of the two groups (partial catch-up and complete catch-up growth) should be $3.3 \mathrm{~g} \cdot \mathrm{kg}^{-1} \cdot \mathrm{d}^{-1}$ and $97 \mathrm{kcal} \cdot \mathrm{kg}^{-1} \cdot \mathrm{d}^{-1}$ and $4.3 \mathrm{~g} \cdot \mathrm{kg}^{-1}$. $\mathrm{d}^{-1}$ and $117 \mathrm{kcal} \cdot \mathrm{kg}^{-1} \cdot \mathrm{d}^{-1}$, respectively, rather than $3.4 \mathrm{~g} \cdot \mathrm{kg}^{-1}$. $\mathrm{d}^{-1}$ and $100 \mathrm{kcal} \cdot \mathrm{kg}^{-1} \cdot \mathrm{d}^{-1}$ and $4.5 \mathrm{~g} \cdot \mathrm{kg}^{-1} \cdot \mathrm{d}^{-1}$ and $117 \mathrm{kcal}$. $\mathrm{kg}^{-1} \cdot \mathrm{d}^{-1}$. According to the model, these intakes should result in mean rates of weight gain of $16.2 \mathrm{~g} \cdot \mathrm{kg}^{-1} \cdot \mathrm{d}^{-1}$ and $21.6 \mathrm{~g} \cdot \mathrm{kg}^{-1}$. $\mathrm{d}^{-1}$, mean rates of protein accretion of $2.45 \mathrm{~g} \cdot \mathrm{kg}^{-1} \cdot \mathrm{d}^{-1}$ and 3.16 $\mathrm{g} \cdot \mathrm{kg}^{-1} \cdot \mathrm{d}^{-1}$, mean rates of fat accretion of $2.18 \mathrm{~g} \cdot \mathrm{kg}^{-1} \cdot \mathrm{d}^{-1}$ and $3.29 \mathrm{~g} \cdot \mathrm{kg}^{-1} \cdot \mathrm{d}^{-1}$, and mean ratios of protein to fat accretion of 1.124 and 0.961 , respectively. It should be noted that the predicted mean rates of weight gain are based on an assumed birth weight of $1400 \mathrm{~g}$ (see equation 1).

Overview of study. LBW infants weighing between 750 and $1750 \mathrm{~g}$ at birth with neither gastrointestinal disease, renal disease, nor severe pulmonary disease were assigned randomly within four birth weight ranges, i.e. 750-1000 g, 1001-1250 g, 1251$1500 \mathrm{~g}$, and $1500-1750 \mathrm{~g}$, to be fed one of three formulas, either one of the combinations of intakes described above (formulas 1 and 2, Table 1) or a third combination (formula 3, Table 1) of $4.2 \mathrm{~g} \cdot \mathrm{kg}^{-1} \cdot \mathrm{d}^{-1}$ protein and $143 \mathrm{kcal} \cdot \mathrm{kg}^{-1} \cdot \mathrm{d}^{-1}$ energy. The known dependence of protein utilization on energy intake $(19,20)$ and our prior observation (11) that a protein intake of $3.9 \mathrm{~g} \cdot \mathrm{kg}^{-1}$. $\mathrm{d}^{-1}$ was not utilized as well at an energy intake of $120 \mathrm{kcal} \cdot \mathrm{kg}^{-1}$. $\mathrm{d}^{-1}$ as at an intake of $140 \mathrm{kcal} \cdot \mathrm{kg}^{-1} \cdot \mathrm{d}^{-1}$ and, hence, the likelihood that the protein intake of $4.3 \mathrm{~g} \cdot \mathrm{kg}^{-1} \cdot \mathrm{d}^{-1}$ would not be maximally utilized at an energy intake of only $117 \mathrm{kcal} \cdot \mathrm{kg}^{-1} \cdot \mathrm{d}^{-1}$ precipitated inclusion of the third combination of intakes. This third combination, according to the model, should result in mean rates of weight gain, protein accretion, and fat accretion of $23.9 \mathrm{~g}$. $\mathrm{kg}^{-1} \cdot \mathrm{d}^{-1}, 3.09 \mathrm{~g} \cdot \mathrm{kg}^{-1} \cdot \mathrm{d}^{-1}$, and $5.33 \mathrm{~g} \cdot \mathrm{kg}^{-1} \cdot \mathrm{d}^{-1}$, respectively. The mean ratio of protein accretion to fat accretion should be 0.579 .

All formulas, prepared specifically for this study by Ross Laboratories, were number-coded and the code was not known to the investigators or the nurses caring for the infants. They were identical except for their content of protein and energy (Table 1). All contained modified bovine milk protein $(60 \%$ whey proteins, $40 \%$ caseins). The nonprotein energy content was composed of $50 \%$ fat ( $25 \%$ medium-chain triglycerides, $30 \%$ coconut oil, and $45 \%$ soy oil) and $50 \%$ carbohydrate (equal amounts of lactose and a glucose polymer). Electrolyte, mineral, and vitamin contents were similar (Table 1) and the same as those of the manufacturer's routine LBW infant formula (Similac Special Care, Ross Laboratories, Columbus, $\mathrm{OH}$ ).

The assigned formula was started as soon as enteral feedings were tolerated, and the volume was increased as tolerated to 180 $\mathrm{mL} \cdot \mathrm{kg}^{-1} \cdot \mathrm{d}^{-1}$. This intake was then maintained by daily adjustments based on each day's weight until the infant weighed 2200 $\mathrm{g}$ or, rarely, until the infant was discharged. Once enteral feedings were established, vitamins A (1500 IU), C (35 mg), D (400 IU), and E (25 IU) were administered to all infants daily.

The formulas were delivered by orogastric tube or by nipple using a syringe or volumetric cylinder. Simulation of these procedures in the laboratory showed that loss of nutrients was negligible. Throughout the study, infants were nursed in servocontrolled incubators at a thermoneutral temperature. As soon as possible, always by the time full intake was tolerated, the infants were transferred to the Neonatal Clinical Research Center, where the study was completed. Growth, nutrient balances, and biochemical variables were monitored, as described below, 
Table 3. Macronutrient balances* of the three study groups

\begin{tabular}{|c|c|c|c|}
\hline & Group 1 & Group 2 & Group 3 \\
\hline \multicolumn{4}{|l|}{ Nitrogen $\left(\mathrm{mg} \cdot \mathrm{kg}^{-1} \cdot \mathrm{d}^{-1}\right)$} \\
\hline Intake & $513.5 \pm 1.6$ & $667.3 \pm 4.9$ & $652.7 \pm 3.1$ \\
\hline Stool & $29.5 \pm 8.6$ & $41.2 \pm 12.4$ & $56.5 \pm 18.8$ \\
\hline Urine & $116.0 \pm 26.7$ & $178.8 \pm 21.5$ & $144.1 \pm 38.5 \dagger$ \\
\hline Balance & $368.1 \pm 31.7$ & $447.3 \pm 28.0$ & $452.2 \pm 38.7$ \\
\hline \multicolumn{4}{|l|}{ Energy $\left(\mathrm{kcal} \cdot \mathrm{kg}^{-1} \cdot \mathrm{d}^{-1}\right)$} \\
\hline Intake & $98.4 \pm 1.5$ & $117.0 \pm 4.7$ & $141.5 \pm 5.6$ \\
\hline Energy expenditure & $59.1 \pm 4.2$ & $62.9 \pm 3.8$ & $68.0 \pm 4.6 \dagger$ \\
\hline Energy stored & $35.3 \pm 4.5$ & $48.4 \pm 6.8$ & $67.1 \pm 5.5 \dagger$ \\
\hline \multicolumn{4}{|l|}{ Sodium $\left(\mathrm{mmol} \cdot \mathrm{kg}^{-1} \cdot \mathrm{d}^{-1}\right)$} \\
\hline Intake & $3.53 \pm 0.01$ & $3.43 \pm 0.03$ & $3.41 \pm 0.02$ \\
\hline Stool & $0.05 \pm 0.02$ & $0.06 \pm 0.03$ & $0.10 \pm 0.05$ \\
\hline Urine & $2.15 \pm 0.35$ & $1.98 \pm 0.32$ & $1.72 \pm 0.35$ \\
\hline Balance & $1.33 \pm 0.36$ & $1.39 \pm 0.32$ & $1.59 \pm 0.33$ \\
\hline Intake & $3.95 \pm 0.01$ & $4.11 \pm 0.03$ & $4.25 \pm 0.02$ \\
\hline Stool & $0.07 \pm 0.03$ & $0.08 \pm 0.03$ & $0.15 \pm 0.09$ \\
\hline Urine & $2.90 \pm 0.23$ & $2.93 \pm 0.18$ & $2.83 \pm 0.36$ \\
\hline Balance & $0.98 \pm 0.23$ & $1.10 \pm 0.16$ & $1.27 \pm 0.36$ \\
\hline \multicolumn{4}{|l|}{ Chloride $\left(\mathrm{mmol} \cdot \mathrm{kg}^{-1} \cdot \mathrm{g}^{-1}\right)$} \\
\hline Intake & $2.87 \pm 0.01$ & $2.85 \pm 0.02$ & $2.80 \pm 0.01$ \\
\hline Stool & $0.03 \pm 0.01$ & $0.03 \pm 0.01$ & $0.04 \pm 0.03$ \\
\hline Urine & $1.58 \pm 0.35$ & $1.44 \pm 0.29$ & $1.23 \pm 0.23$ \\
\hline Balance & $1.27 \pm 0.35$ & $1.39 \pm 0.29$ & $1.53 \pm 0.22$ \\
\hline \multicolumn{4}{|l|}{ Calcium $\left(\mathrm{mmol} \cdot \mathrm{kg}^{-1} \cdot \mathrm{d}^{-1}\right)$} \\
\hline Intake & $6.34 \pm 0.02$ & $6.20 \pm 0.05$ & $6.10 \pm 0.03$ \\
\hline Stool & $2.60 \pm 1.03$ & $2.65 \pm 0.92$ & $2.30 \pm 0.74$ \\
\hline Urine & $0.10 \pm 0.07$ & $0.10 \pm 0.04$ & $0.10 \pm 0.08$ \\
\hline Balance & $3.63 \pm 1.02$ & $3.45 \pm 0.95$ & $3.75 \pm 0.74$ \\
\hline \multicolumn{4}{|c|}{ Magnesium $\left(\mathrm{mmol} \cdot \mathrm{kg}^{-1} \cdot \mathrm{d}^{-1}\right)$} \\
\hline Intake & $0.71 \pm 0.00$ & $0.68 \pm 0.01$ & $0.67 \pm 0.01$ \\
\hline Balance & $0.32 \pm 0.12$ & $0.33 \pm 0.11$ & $0.34 \pm 0.08$ \\
\hline \multicolumn{4}{|c|}{ Phosphorus $\left(\mathrm{mmol} \cdot \mathrm{kg}^{-1} \cdot \mathrm{d}^{-1}\right)$} \\
\hline Intake & $4.24 \pm 0.01$ & $4.32 \pm 0.03$ & $4.13 \pm 0.02$ \\
\hline Stool & $1.39 \pm 0.55$ & $1.38 \pm 0.56$ & $1.19 \pm 0.35$ \\
\hline Urine & $0.26 \pm 0.1$ & $0.50 \pm 0.14$ & $0.46 \pm 0.16$ \\
\hline Balance & $2.59 \pm 0.55$ & $2.46 \pm 0.52$ & $2.48 \pm 0.43$ \\
\hline
\end{tabular}

$*$ Mean \pm SD.

$\dagger p<0.01$, group 3 vs group 2 .

Table 4. Growth rates* of the three study groups

\begin{tabular}{lccc}
\hline \multicolumn{1}{c}{ Variable } & Group 1 & \multicolumn{1}{c}{ Group 2 } & Group 3 \\
\hline$\Delta$ Weight $\left(\mathrm{g} \cdot \mathrm{kg}^{-1} \cdot \mathrm{d}^{-1}\right)$ & $16.2 \pm 2.7$ & $19.7 \pm 3.5$ & $24.0 \pm 2.8 \dagger$ \\
$\begin{array}{c}\Delta \text { Crown-heel length } \\
\text { (cm/wk) }\end{array}$ & $1.15 \pm 0.23$ & $1.20 \pm 0.28$ & $1.39 \pm 0.29$ \\
$\begin{array}{c}\Delta \text { Head circumference } \\
\text { (cm/wk) }\end{array}$ & $1.13 \pm 0.18$ & $1.17 \pm 0.18$ & $1.30 \pm 0.13$ \\
$\begin{array}{c}\Delta \text { Triceps skinfold thick- } \\
\text { ness (mm/wk) }\end{array}$ & $0.29 \pm 0.12$ & $0.37 \pm 0.15$ & $0.74 \pm 0.27 \dagger$ \\
$\begin{array}{c}\Delta \text { Subscapular skinfold } \\
\text { thickness (mm/wk) }\end{array}$ & $0.33 \pm 0.14$ & $0.48 \pm 0.18$ & $0.91 \pm 0.25 \dagger$ \\
\hline *Mean \pm SD. & & & \\
$\quad+p<0.01$, group 3 vs group 2. & &
\end{tabular}

from the time desired intake was tolerated until weight reached $2200 \mathrm{~g}$.

The study was approved by the institutional review board and informed parental consent was obtained before an infant was enrolled.

Growth. Body weight was measured each morning before feeding using a scale with a resolution of $1 \mathrm{~g}$. The daily weights of each infant were regressed against the infant's age in days, and the rate of weight gain over the entire period of study, expressed as $\mathrm{g} \cdot \mathrm{kg}^{-1} \cdot \mathrm{d}^{-1}$, was computed for each infant. Crown-heel length, head circumference, and the thickness of both triceps and subscapular skinfolds were measured weekly, always by the same two investigators, using standard procedures (10). Each measurement was regressed against age, and the rates of change over the entire period of study expressed as $\mathrm{cm}$ or $\mathrm{mm} / \mathrm{wk}$ were computed. The study period ranged from 17 to $42 \mathrm{~d}$ (mean $\pm \mathrm{SD}$, $29.6 \pm 7.1 \mathrm{~d})$ for group 1 , from 11 to $51 \mathrm{~d}(25.3 \pm 9.8 \mathrm{~d})$ for group 2 , and from 10 to $40 \mathrm{~d}(20.3 \pm 7.5 \mathrm{~d})$ for group 3 .

Nutrient balances. Seventy-two-hour collections of stool and urine were obtained, using standard procedures described previously (11), within the first week after the infants had received the desired intake $\left(180 \mathrm{~mL} \cdot \mathrm{kg}^{-1} \cdot \mathrm{d}^{-1}\right)$ and every other week thereafter until weight reached $2200 \mathrm{~g}$ or, occasionally, until the child was discharged at a lower weight. The intent was to obtain a minimum of two collections from each infant. Because of early discharge, only one collection was obtained from two infants; of the remainder, two collections were obtained from 21 infants, three collections were obtained from 16 infants, four collections were obtained from three infants, and five collections were obtained from two infants.

Nitrogen, electrolyte, and mineral balances were computed as the difference between intake and the sum of urinary and fecal 
Table 5. Predicted and observed outcome variables of each infant in the three study groups

\begin{tabular}{|c|c|c|c|c|c|c|c|c|}
\hline \multirow[b]{2}{*}{ Birth weight (g) } & \multicolumn{2}{|c|}{ Weight gain $\left(g \cdot \mathrm{kg}^{-1} \cdot \mathrm{d}^{-1}\right)$} & \multicolumn{2}{|c|}{ Protein stored $\left(\mathrm{g} \cdot \mathrm{kg}^{-1} \cdot \mathrm{d}^{-1}\right)$} & \multicolumn{2}{|c|}{ Fat stored $\left(g \cdot \mathrm{kg}^{-1} \cdot \mathrm{d}^{-1}\right)$} & \multicolumn{2}{|c|}{ Protein stored/fat stored } \\
\hline & Predicted* & Observed & Predicted* & Observed & Predicted ${ }^{*}$ & Observed & Predicted* & Observed \\
\hline \multicolumn{9}{|l|}{ Group 1} \\
\hline 1060 & 17.9 & 19.3 & 2.38 & 2.37 & 2.38 & 2.96 & 0.9975 & 0.8002 \\
\hline 1100 & 17.7 & 21.2 & 2.38 & 2.35 & 2.37 & 2.89 & 1.0043 & 0.8141 \\
\hline 1320 & 16.7 & 15.9 & 2.38 & 1.96 & 2.37 & 2.43 & 1.0034 & 0.8093 \\
\hline 1270 & 16.9 & 13.4 & 2.38 & 2.25 & 2.37 & 2.32 & 1.0067 & 0.9678 \\
\hline 1760 & 14.5 & 14.4 & 2.37 & 2.04 & 2.34 & 2.50 & 1.0152 & 0.8163 \\
\hline 1300 & 15.5 & 14.7 & 2.24 & 2.46 & 2.03 & 1.41 & 1.1030 & 1.7424 \\
\hline 1675 & 15.1 & 12.7 & 2.39 & 2.25 & 2.39 & 3.01 & 1.0020 & 0.7468 \\
\hline 1505 & 15.8 & 13.3 & 2.39 & 2.08 & 2.37 & 2.57 & 1.0055 & 0.8061 \\
\hline 1265 & 17.0 & 17.1 & 2.39 & 2.37 & 2.39 & 2.04 & 1.0003 & 1.1650 \\
\hline 790 & 19.3 & 14.7 & 2.39 & 2.54 & 2.44 & 1.70 & 0.9820 & 1.4988 \\
\hline 1320 & 16.7 & 20.2 & 2.39 & 2.57 & 2.38 & 3.11 & 1.0029 & 0.8276 \\
\hline 1105 & 17.5 & 18.9 & 2.36 & 2.24 & 2.33 & 2.19 & 1.0167 & 1.0208 \\
\hline 1200 & 17.3 & 16.6 & 2.39 & 2.15 & 2.39 & 2.22 & 0.9994 & 0.9666 \\
\hline 1650 & 15.1 & 15.0 & 2.38 & 2.34 & 2.37 & 2.48 & 1.0064 & 0.9435 \\
\hline Mean & 16.7 & 16.2 & 2.37 & 2.28 & 2.35 & 2.42 & 1.0104 & 0.9947 \\
\hline SD & 1.3 & 2.7 & 0.04 & 0.18 & 0.09 & 0.49 & 0.0279 & 0.2920 \\
\hline \multicolumn{9}{|l|}{ Group 2} \\
\hline 1500 & 20.8 & 16.3 & 3.01 & 2.83 & 3.35 & 3.75 & 0.9012 & 0.7554 \\
\hline 1320 & 18.7 & 16.3 & 2.68 & 1.95 & 2.60 & 2.07 & 1.0299 & 0.9438 \\
\hline 1320 & 22.1 & 22.0 & 3.08 & 2.76 & 3.44 & 3.69 & 0.8933 & 0.7463 \\
\hline 1720 & 20.2 & 26.5 & 3.07 & 3.15 & 3.43 & 3.18 & 0.8964 & 0.9900 \\
\hline 1340 & 20.9 & 20.4 & 2.95 & 2.60 & 3.15 & 4.26 & 0.9384 & 0.6105 \\
\hline 1170 & 22.7 & 16.8 & 3.07 & 2.82 & 3.42 & 2.98 & 0.8962 & 0.9464 \\
\hline 780 & 24.1 & 17.4 & 3.01 & 2.71 & 3.28 & 2.98 & 0.9195 & 0.9090 \\
\hline 1680 & 21.6 & 15.8 & 3.12 & 2.83 & 4.17 & 4.77 & 0.7476 & 0.5928 \\
\hline 1070 & 23.3 & 20.7 & 3.08 & 2.98 & 3.46 & 3.72 & 0.8901 & 0.8014 \\
\hline 1515 & 21.2 & 19.8 & 3.08 & 2.71 & 3.45 & 3.29 & 0.8929 & 0.8245 \\
\hline 1100 & 23.0 & 22.6 & 3.06 & 2.60 & 3.43 & 3.62 & 0.8931 & 0.7174 \\
\hline 1285 & 22.3 & 17.3 & 3.08 & 2.72 & 3.46 & 3.22 & 0.8903 & 0.8462 \\
\hline 1650 & 20.6 & 16.2 & 3.08 & 2.82 & 3.44 & 3.77 & 0.8963 & 0.7479 \\
\hline 1230 & 22.5 & 26.0 & 3.07 & 2.94 & 3.44 & 4.08 & 0.8933 & 0.7211 \\
\hline 1460 & 21.4 & 20.9 & 3.07 & 2.78 & 3.43 & 3.95 & 0.8964 & 0.7029 \\
\hline Mean & 21.7 & 19.7 & 3.03 & $2.75 \dagger$ & 3.40 & 3.56 & 0.8983 & $0.7904 \dagger$ \\
\hline SD & 1.4 & 3.5 & 0.11 & 0.26 & 0.31 & 0.64 & 0.0550 & 0.1196 \\
\hline \multicolumn{9}{|l|}{ Group 3} \\
\hline 1410 & 23.8 & 18.9 & 3.01 & 2.28 & 5.47 & 5.95 & 0.5499 & 0.3832 \\
\hline 1390 & 23.8 & 23.3 & 3.00 & 2.73 & 5.45 & 6.05 & 0.5502 & 0.4518 \\
\hline 1220 & 24.3 & 25.9 & 2.97 & 2.82 & 5.36 & 5.58 & 0.5545 & 0.5065 \\
\hline 1300 & 24.3 & 27.1 & 3.01 & 2.87 & 5.48 & 5.86 & 0.5489 & 0.4902 \\
\hline 1280 & 24.4 & 23.4 & 3.01 & 2.43 & 5.48 & 6.37 & 0.5487 & 0.3817 \\
\hline 1165 & 24.9 & 20.8 & 3.01 & 2.80 & 5.48 & 5.46 & 0.5485 & 0.5131 \\
\hline 1655 & 21.2 & 26.9 & 2.85 & 2.55 & 5.02 & 5.07 & 0.5682 & 0.5035 \\
\hline 1570 & 22.9 & 21.2 & 2.99 & 3.08 & 5.42 & 4.85 & 0.5517 & 0.6356 \\
\hline 760 & 26.8 & 23.5 & 3.01 & 2.89 & 5.49 & 5.72 & 0.5475 & 0.5051 \\
\hline 1555 & 22.6 & 26.7 & 2.95 & 2.98 & 5.30 & 5.81 & 0.5571 & 0.5134 \\
\hline 1090 & 25.3 & 20.7 & 3.01 & 2.77 & 5.48 & 4.11 & 0.5489 & 0.6741 \\
\hline 1260 & 24.3 & 27.8 & 2.99 & 2.89 & 5.42 & 5.81 & 0.5524 & 0.4970 \\
\hline 1390 & 23.8 & 25.4 & 2.99 & 3.13 & 5.46 & 4.80 & 0.5481 & 0.5065 \\
\hline 1250 & 24.4 & 24.2 & 2.99 & 2.93 & 5.45 & 6.12 & 0.5495 & 0.4787 \\
\hline Mean & 24.0 & 24.0 & 2.95 & 2.80 & 5.32 & 5.54 & 0.5554 & 0.5133 \\
\hline SD & 1.3 & 2.8 & 0.13 & 0.24 & 0.35 & 0.62 & 0.0154 & 0.0879 \\
\hline
\end{tabular}

* The predicted variables were calculated using the appropriate equations composing the model, the birth weight of each infant, and the actual protein and energy intakes of each for the entire study period.

† Significantly different from predicted.

losses. Total nitrogen content of the formulas, urine, and stool was measured by the Dumas method using a Coleman model 129 automatic nitrogen analyzer (Perkin-Elmer Corp., Norwalk, CT). Concentrations of sodium and potassium were determined by flame photometry, those of chloride by microcoulometric titration (21), those of calcium and magnesium by atomic absorption spectrometry, and those of phosphorus by the method of Baginski et al. (22).

Energy balances, computed as the difference between gross energy intake and the sum of excretory energy losses and energy expenditure, were performed during each 72-h urine and stool collection period. The energy contents of the intake and stool were determined by bomb calorimetry (23); the energy content of urine was calculated as $5.4 \mathrm{kcal}$ of urinary urea nitrogen per gram [the heat of combustion of urea (24)]. Energy expenditure was computed from 6-h measurements of oxygen consumption and carbon dioxide production and from urinary nitrogen excretion during the $72-\mathrm{h}$ collection period, using the constants of Lusk (25). The open circuit, indirect calorimetry system used to measure oxygen consumption and carbon dioxide production has been described previously (26).

Biochemical variables. Plasma albumin and transthyretin con- 

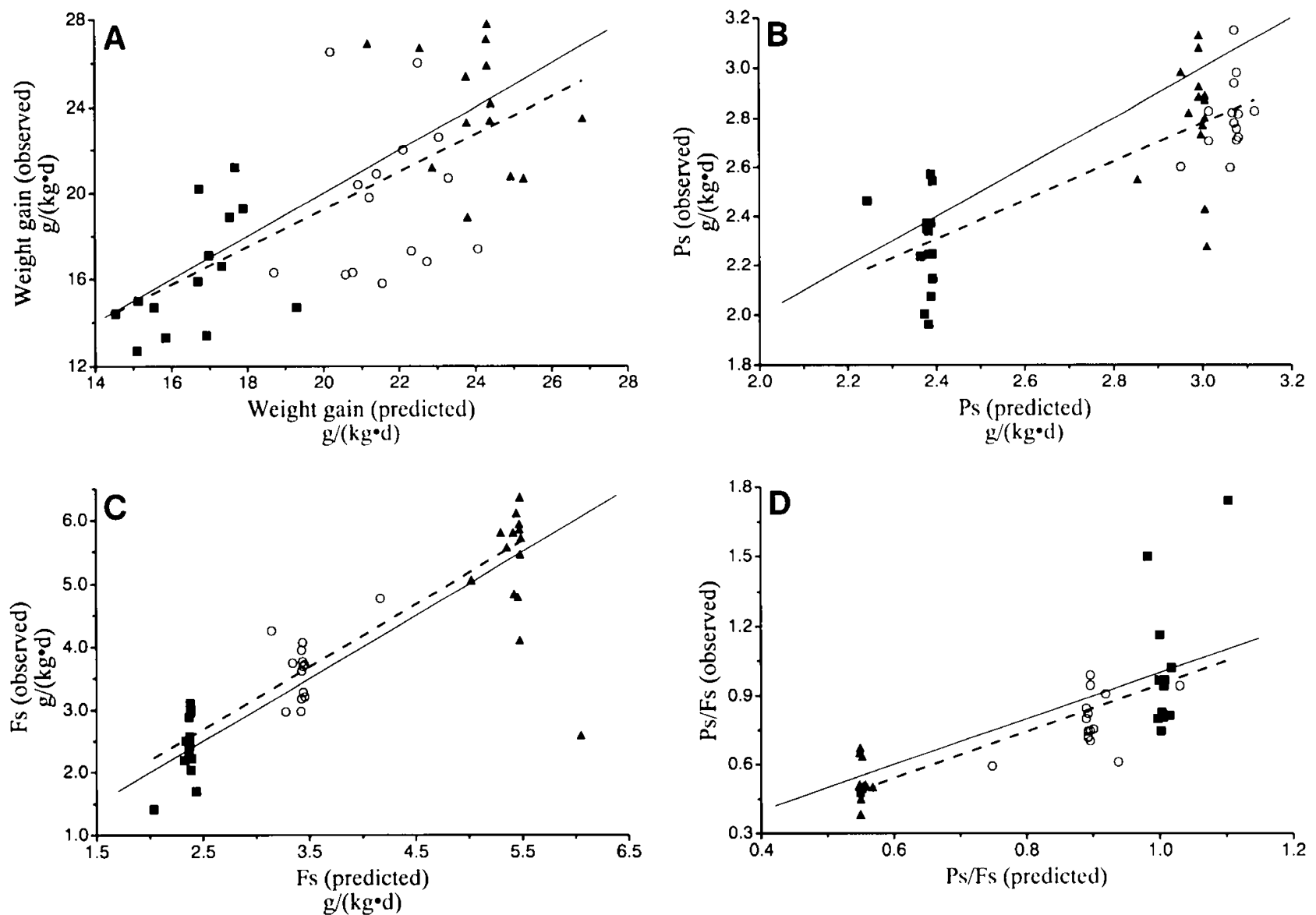

Fig. 1. Relationship between outcome variables predicted and those observed in the three study groups (group 1, $\mathbf{\square} ;$ group $2.0 ;$ group 3, $\mathbf{\Delta}$ ). $A$, Rate of weight gain $\left(\mathrm{y}=0.873 \pm 0.15 \mathrm{x}-1.78 \pm 3.2, r^{2}=0.44\right) ; B$, protein accretion $(P S)\left(\mathrm{y}=0.804 \pm 0.105 \mathrm{x}+0.359 \pm 0.295, r^{2}=0.58\right) ; C$, fat accretion $(F s)\left(\mathrm{y}=1.03 \pm 0.06 \mathrm{x}+0.018 \pm 0.24 . r^{2}=0.87\right)$; and $D$, ratio of protein accretion to fat accretion $(P S / F s)(\mathrm{y}=1.02 \pm 0.14 \mathrm{x}-0.073 \pm$ $\left.0.12, r^{2}=0.56\right)$. For all, the regression line (broken line) does not differ significantly from the line of identity ( (solid line): $A, p=0.4 ; B, p=0.09 ; C$, $p=0.35 ;$ and $D, p=0.56$.

centrations were determined every other week, the former by the Clinical Chemistry Laboratory of Presbyterian Hospital and the latter in the investigators' laboratory by radial immunodiffusion using an M-Partigen Kit (Behring Diagnostics, La Jolla, CA). Blood urea nitrogen concentration and acid-base status were determined weekly by the Clinical Chemistry Laboratory of Presbyterian Hospital. Plasma amino acid concentrations were determined every other week by column chromatography using a Beckman 121-MB amino acid analyzer (Beckman Instruments, Inc., Palo Alto, CA).

Data analysis. Clinical characteristics assessable on a continuous scale were summarized as mean $\pm \mathrm{SD}$; dichotomous characteristics (present/absent) were summarized simply by enumerating the number of subjects with each characteristic.

The mean slope of the linear regression of each outcome variable against postnatal age was calculated for each group, using the slope of each subject, and tested to determine whether it was statistically significant. If so for any group, the slope of the variable for each subject and the expected value when weight reached $2200 \mathrm{~g}$ were used for further analyses. For variables without a significant slope, the mean value for each subject during the period of study was used for further analysis.

The primary analyses required to achieve the objectives of this study are those necessary to test the validity of the model (i.e. to determine differences between observed and predicted outcomes) and those necessary to detect the effect of energy intake on protein utilization (i.e. to determine differences in selected outcome variables between groups 2 and 3). For the former, the observed rates of weight gain, protein accretion, and fat accretion of each infant as well as the ratio of protein to fat accretion were compared by regression analysis with the predicted rate or ratio, calculated from the equations composing the model, the infant's birth weight, and the infant's actual protein and energy intakes over the period of study. In addition, the difference between observed and predicted variables of each infant was plotted against the mean value of the observed and predicted variable (27), and the $95 \%$ confidence interval of the mean difference was calculated. To determine whether the validity of the model differed among groups, the observed group mean of each outcome variable was compared by $t$ test to the predicted group mean; differences at $p<0.01$ were designated statistically significant. To determine differences in protein utilization secondary to additional energy intake. differences in selected outcome variables between groups 2 and 3 were compared by $t$ test; differences at $p<0.01$ were designated statistically significant.

Outcome variables determined as part of the study but not particularly germane to the primary or secondary objectives are presented without designation of statistically significant differences among groups.

\section{RESULTS}

Study population. Five of the 49 subjects enrolled in the study did not complete it; three developed necrotizing enterocolitis, one developed patent ductus arteriosus requiring fluid restriction, and one developed neonatal diabetes. As summarized in Table 2 , the clinical characteristics of the 44 infants who completed the study differed minimally among groups. The clinical characteristics of these infants also differed minimally from infants studied 

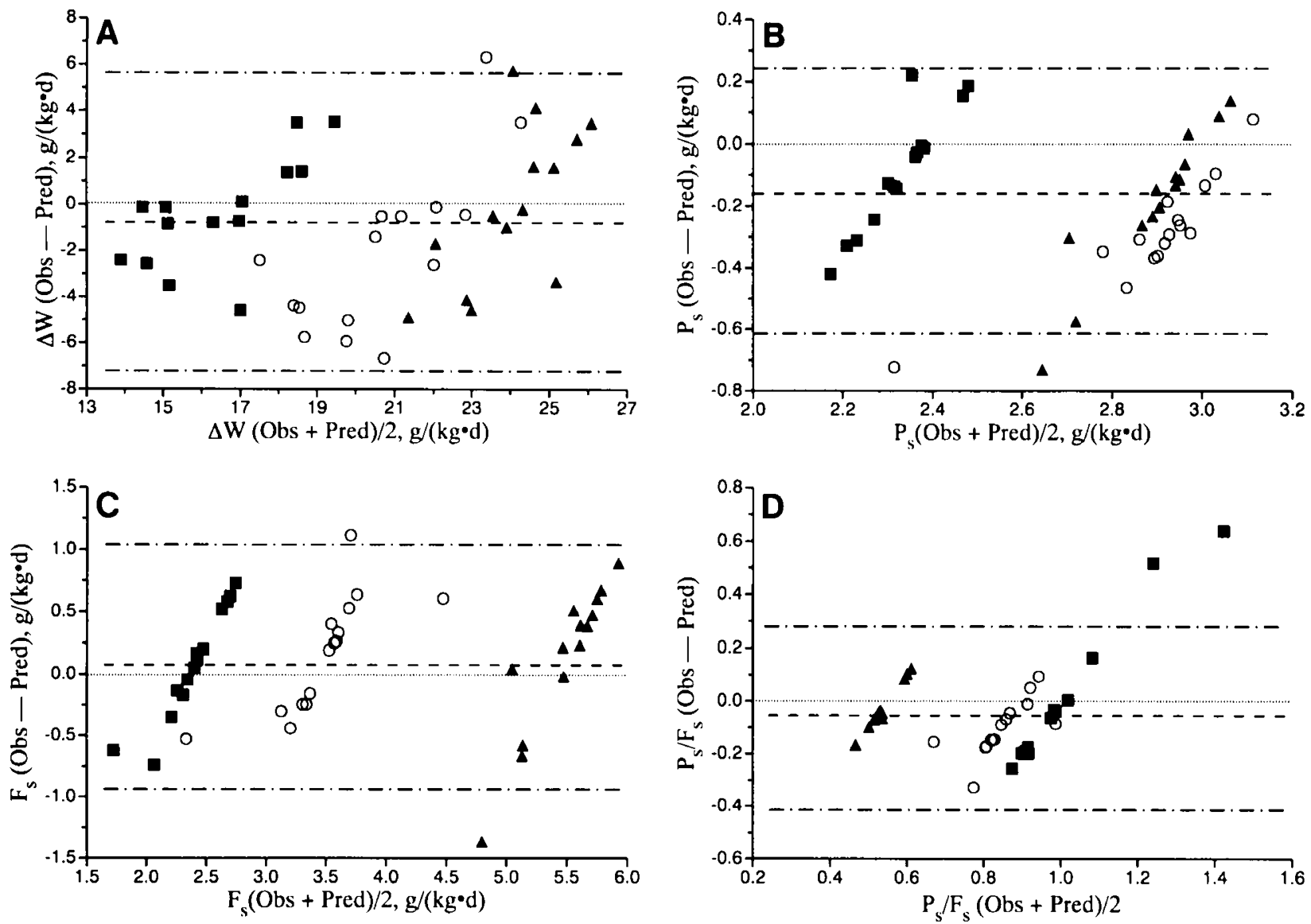

Fig. 2. Differences between observed and predicted outcome variables in the three study groups (group 1, $\square$; group 2, O; group 3, $\Delta$ ) plotted against the average of observed and predicted variables (27). $A$, Rate of weight gain [mean difference $(---),-0.86 \mathrm{~g} \cdot \mathrm{kg}^{-1} \cdot \mathrm{d}^{-1} ; 95 \%$ confidence interval of agreement $(\cdot-\cdot),-7.34$ to $\left.5.6 \mathrm{~g} \cdot \mathrm{kg}^{-1} \cdot \mathrm{d}^{-1} \mathrm{l}\right) ; B$, protein accretion (mean difference, $-0.19 \mathrm{~g} \cdot \mathrm{kg}^{-1} \cdot \mathrm{d}^{-1} ; 95 \%$ confidence interval of agreement, -0.62 to $0.24 \mathrm{~g} \cdot \mathrm{kg}^{-1} \cdot \mathrm{d}^{-1}$ ); $C$, fat accretion (mean difference, $0.12 \mathrm{~g} \cdot \mathrm{kg}^{-1} \cdot \mathrm{d}^{-1} ; 95 \%$ confidence interval of agreement, -0.89 to $1.13 \mathrm{~g}$. $\mathrm{kg}^{-1} \cdot \mathrm{d}^{-1}$ ); and $D$, ratio of protein accretion to fat accretion (mean difference, $-0.055 ; 95 \%$ confidence interval of agreement, -0.41 to $0.30 \mathrm{~g} \cdot \mathrm{kg}^{-1}$. $\mathrm{d}^{-1}$ ).

previously $(3,10-13)$, although the lower birth weight limit for inclusion in previous studies was $900 \mathrm{~g}$ rather than $750 \mathrm{~g}$.

Nutrient intakes. The mean volume of intake of all infants was very close to that intended. Thus, the actual intakes of these groups differed only minimally from expected intakes based on the nutrient contents of the formulas (Table 1) and vitamin supplements. The mean intakes of the major nutrients by the three groups are summarized in Table 3.

Growth and nutrient retention. The group means of all outcome variables related to growth and nutrient retention are shown in Tables 3 and 4 . In general, differences in outcome variables between groups 2 and 3 were those expected from the greater energy intake of group 3 versus group 2 (see below).

Predicted versus observed outcomes. The predicted and observed rates of weight gain, protein accretion, and fat accretion as well as the ratio of protein to fat accretion of each infant assigned to each group are shown in Table 5 . The predicted rates and ratios are based on each infant's actual birth weight and mean intake of protein and energy over the entire study period. The relationships between the rates of weight gain, protein accretion, and fat accretion as well as the ratio of protein to fat accretion observed in each infant assigned to the three groups and the predicted rates or ratio are shown in Figure 1. For each outcome variable, the correlation between the observed and predicted values was highly significant.

In addition, the slopes of the regression lines relating the observed and predicted variables did not differ from 1.0 (the line of identity).

The difference between the observed and predicted rates and ratio of each infant in all groups plotted against the mean value of the observed and predicted variables (27) is shown in Figure 2. For each variable, the mean difference of the population was very close to zero. However, the $95 \%$ confidence intervals for the mean difference between observed and predicted variables were quite wide.

As illustrated in Table 5, the mean rate of protein accretion of group 2 and, hence, the ratio of protein to fat accretion were significantly less than predicted. In addition, the mean difference between the rate of protein accretion of group 2 and the predicted rate (i.e. $-0.29 \pm 0.18 \mathrm{~g} \cdot \mathrm{kg}^{-1} \cdot \mathrm{d}^{-1}$ ) is greater than the residual error of the equation for nitrogen retention on which the model is partially based (i.e. $\pm 0.026 \mathrm{~g} \cdot \mathrm{kg}^{-1} \cdot \mathrm{d}^{-1}$ of nitrogen or $0.16 \mathrm{~g}$. $\mathrm{kg}^{-1} \cdot \mathrm{d}^{-1}$ of protein).

Indices of protein adequacy/excess. The plasma transthyretin concentration of group 3 increased significantly during the study period $\left(1.08 \pm 1.54 \mathrm{mg} \cdot \mathrm{dL}^{-1} \cdot \mathrm{wk}^{-1}\right)$; that of groups 1 and $2 \mathrm{did}$ not $\left(0.1 \pm 0.54\right.$ and $0.59 \pm 1.20 \mathrm{mg} \cdot \mathrm{dL}^{-1} \cdot \mathrm{wk}^{-1}$, respectively) Plasma albumin concentrations of groups 1 and 2 but not group 3 rose significantly during the study period $(0.06 \pm 0.08,0.06 \pm$ 0.10 , and $0.09 \pm 0.17 \mathrm{~g} \cdot \mathrm{dL}^{-1} \cdot \mathrm{wk}^{-1}$ in groups 1,2 , and 3 , respectively). At $2200 \mathrm{~g}$, plasma transthyretin concentrations of groups 1,2 , and 3 were $12.1 \pm 2.1,13.8 \pm 2.2$, and $13.6 \pm 2.0$ $\mathrm{mg} / \mathrm{dL}$, respectively; plasma albumin concentrations of the three groups were $3.4 \pm 0.3,3.6 \pm 0.3$, and $3.3 \pm 0.3 \mathrm{~g} / \mathrm{dL}$.

The blood urea nitrogen concentration of groups 2 and 3 but not group 1 increased significantly during the study period $(0.64$ $\pm 1.52,2.02 \pm 1.72$, and $1.87 \pm 2.0 \mathrm{mg} \cdot \mathrm{dL}^{-1} \cdot \mathrm{wk}^{-1}$ in groups 1 , 2 , and 3 , respectively). The mean concentrations at $2200 \mathrm{~g}$ were 
Table 6. Plasma amino acid concentrations $(\mu \mathrm{mol} / \mathrm{L})^{*}$ of the three study groups

\begin{tabular}{lccc}
\hline \multicolumn{1}{c}{ Amino acid } & Group 1 & Group 2 & Group 3 \\
\hline Threonine & $391 \pm 77$ & $483 \pm 140$ & $520 \pm 162$ \\
Valine & $167 \pm 23$ & $228 \pm 24$ & $221 \pm 32$ \\
Leucine & $100 \pm 15$ & $142 \pm 21$ & $137 \pm 19$ \\
Isoleucine & $67 \pm 9$ & $95 \pm 13$ & $95 \pm 12$ \\
Lysine & $195 \pm 34$ & $263 \pm 35$ & $244 \pm 40$ \\
Methionine & $30 \pm 0.5$ & $5.0 \pm 0.5$ & $4.9 \pm 0.9$ \\
Cystine (free) & $34 \pm 6$ & $38 \pm 5$ & $29 \pm 8$ \\
Histidine & $78 \pm 16$ & $94 \pm 12$ & $80 \pm 19$ \\
Phenylalanine & $61 \pm 9$ & $71 \pm 7$ & $71 \pm 9$ \\
Tyrosine & $117 \pm 24$ & $167 \pm 48$ & $137 \pm 57$ \\
Tryptophan (total) $\dagger$ & $41 \pm 12$ & $42 \pm 12$ & $41 \pm 9$ \\
Serine & $271 \pm 65$ & $269 \pm 42$ & $271 \pm 70$ \\
Glutamic acid & $59 \pm 9$ & $72 \pm 17$ & $85 \pm 35$ \\
Proline & $190 \pm 30$ & $241 \pm 48$ & $266 \pm 47$ \\
Citrulline & $36 \pm 8$ & $37 \pm 12$ & $35 \pm 10$ \\
Glycine & $305 \pm 48$ & $264 \pm 65$ & $296 \pm 69$ \\
Alanine & $288 \pm 53$ & $334 \pm 32$ & $415 \pm 77$ \\
Ornithine & $131 \pm 40$ & $148 \pm 27$ & $138 \pm 41$ \\
Arginine & $113 \pm 29$ & $131 \pm 33$ & $120 \pm 36$ \\
Taurine & $85 \pm 22$ & $87 \pm 19$ & $82 \pm 20$ \\
Aspartic acid & $63 \pm 13$ & $70 \pm 18$ & $74 \pm 20$ \\
Glutamine & $934 \pm 174$ & $889 \pm 88$ & $1074 \pm 270$ \\
Asparagine & $36 \pm 10$ & $38 \pm 10$ & $35 \pm 15$ \\
\hline Mean \pm SD. & & &
\end{tabular}

* Mean \pm SD.

† Plasma prepared as described by Mondino et al. (29).

$9.2 \pm 3.7,13.8 \pm 2.8$, and $10.5 \pm 4.3 \mathrm{mg} / \mathrm{dL}$ in groups 1,2 , and 3 , respectively. Blood acid-base status was within normal limits in all infants throughout the study period.

The mean plasma concentrations of all amino acids of the three study groups are shown in Table 6 . With the exception of the concentrations of threonine and tyrosine in groups 2 and 3 , the mean concentrations of all were within the $95 \%$ confidence limits $( \pm 2 \mathrm{SD})$ of cord plasma concentrations between $29 \mathrm{wk}$ gestation and term (30).

Effect of energy intake on nitrogen utilization. Group 3 was included in this study primarily to obtain additional information concerning the effect of energy intake on nitrogen utilization. Differences in outcome variables between this group and group 2 , the intakes of which differed primarily in total energy, should reflect this effect. Interestingly, the differences were minimal. Urinary nitrogen excretion of group 3 was significantly less than that of group 2 (Table 3), but because of the somewhat lower nitrogen intake and greater fecal nitrogen loss of group 3, the difference in nitrogen retention between the two groups was not statistically significant. The differences in biochemical variables between the two groups (i.e. a somewhat lower rate of increase in blood urea nitrogen concentration as well as a lower blood urea nitrogen concentration at $2200 \mathrm{~g}$ in group 3 versus group 2 and lower plasma concentrations of most essential amino acids in group 3 versus group 2), although not statistically significant, also suggest a modest complementary effect of energy intake on nitrogen utilization. Other differences between the two groups, i.e. the greater rates of weight gain and increases in skinfold thicknesses of group 3 versus group 2 as well as the greater energy expenditure, energy balance, and rate of fat accretion, were expected from the roughly $25 \mathrm{kcal} \cdot \mathrm{kg}^{-1} \cdot \mathrm{d}^{-1}$ difference in energy intake between the two groups.

\section{DISCUSSION}

The foregoing sections describe the development of a model to predict the relationship between protein and energy intakes of LBW infants and the rate and composition of weight gain, the use of this model to predict intakes necessary to produce specific rates of weight gain with the same composition as that of the developing fetus, and evaluation of the model by comparison of the responses of LBW infants fed three protein and energy intake combinations with the responses predicted by the model. Data concerning the metabolic tolerance of the intakes studied as well as data concerning the effect of energy intake on protein utilization also are reported.

On average, the model seems to be remarkably valid for the total population studied. Across all groups, there was a strong correlation between observed and predicted rates of weight gain, protein accretion, fat accretion, and the ratio of protein to fat accretion (Fig. 1). Moreover, the slopes of the regression lines relating the observed and predicted rates or ratio did not differ from the line of identity.

In contrast to the model's validity for predicting the mean outcomes of a population, the model seems to be less valid for predicting the response of an individual infant. Although the mean differences between observed and predicted rates of weight gain, protein accretion, and fat accretion and the ratio of protein to fat accretion were minimal, the limits of agreement were quite wide (Fig. 2). For example, the response of individual infants could be almost precisely that predicted or could differ from that predicted by as much as $\pm 30 \%$. Also, as is clear from perusal of Table 5, there is no consistency in the responses of individual infants among the different variables. The response with respect to one of the variables can be precisely that predicted, but the response with respect to the others can be either greater than or less than predicted.

This difference in validity of the model for a population versus an individual infant is not surprising. The equations composing the model describe the composite behavior of 101 infants rather than that of any single infant and therefore tend to average the myriad of factors that are known or thought to play a role in how an individual infant uses protein and energy intakes for growth. In fact, considering the number of such factors, it is surprising that the limits of agreement between observed and predicted outcomes are as small as those observed.

Interestingly, in this study, birth weight, gestational age, and size for gestational age, all of which are thought to influence the way in which infants utilize protein and energy for growth, seem to explain little of the difference between observed and predicted outcomes. The correlation coefficients for the deviation of the observed rate from the predicted rate of weight gain of each infant and the infant's birth weight, gestational age, and size for gestational age were $0.15,-0.06$, and 0.3 , respectively. The correlation coefficients for the deviation of the observed rates from the predicted rates of protein accretion and these factors $(0.06,0.10$, and -0.02$)$, fat accretion and these factors $(0.07$, -0.22 , and 0.45 ), and the ratio of protein to fat accretion and these factors $(0.05,0.25$, and -0.34$)$ also were low.

Because the protein contents of the formulas manufactured for this study were somewhat less than intended, one of our initial goals, i.e. to determine whether it is possible to produce a rate of weight gain of sufficient magnitude and of the requisite composition to result, at discharge, in the infant's weighing the same and having the same body composition as a fetus of comparable postconceptional age, was not achieved. Nonetheless, the results suggest that this is not likely to be possible. The group of infants fed a somewhat lower protein intake than predicted by the model to result in this goal, i.e. group 2 , who had a protein intake of $4.3 \mathrm{~g} \cdot \mathrm{kg}^{-1} \cdot \mathrm{d}^{-1}$ rather than the predicted intake of $4.5 \mathrm{~g} \cdot \mathrm{kg}^{-1} \cdot \mathrm{d}^{-1}$, retained protein at a significantly lower rate than expected. In addition, the blood urea nitrogen concentration of this group and the plasma concentration of some amino acids (e.g. tyrosine) were higher than might be desirable.

The reason for the poorer-than-expected retention of the high protein intake of group 2 is not clear, but the data reported are consistent with the possibility that utilization of this relatively high protein intake was limited by inadequate energy intake. Certainly, the complementary effect of energy intake on protein utilization is a widely recognized phenomenon $(19,20)$. More- 
over, our earlier data suggested that the predicted energy intake would not support maximal utilization of the protein intake predicted to result in "complete" catch-up growth (11). However, the minimal difference in nitrogen utilization between groups 2 and 3 raises the additional possibility that a protein intake of this magnitude may exceed the capacity of LBW infants for protein utilization regardless of concomitant energy intake. Alternatively, the energy intake required for significantly better utilization of this relatively large protein intake may be even higher than that of group 3. Even if tolerated, such an energy intake is likely to result in an even greater rate of fat deposition than observed in group 3.

In toto, the data reported show that significant catch-up growth without rates of fat accretion vastly in excess of the intrauterine rate can be achieved. However, the protein:energy ratio of the intake required is higher than that of current LBW infant formulas. Moreover, unless synthetic mechanisms can be altered to enhance protein synthesis at the expense of fat deposition, the dual goal of mimicking the quality of fetal tissue deposition and producing complete catch-up growth in LBW infants seems unreachable. Possible strategies for altering the relative rates of protein and fat deposition include varying the quality of dietary protein intakes, energy intakes, or both and exogenous administration of metabolic stimulants (e.g. growth hormone, IGF-1). At present, data supporting the likelihood of success with the former maneuver are limited $(31,32)$; the latter strategy, although effective in animals (33), older children (34), and adults (35), has not been evaluated in LBW infants.

It is important to note that the purpose of the study reported here was not to determine the desirability of one type of growth versus another, but rather to determine the extent to which the rate and quality of growth of LBW infants are influenced by the quality of the diet and the extent to which the quality of growth is predictable-a necessary first step before the advantages and disadvantages of one type of growth versus another can be determined. The findings show that the rate and quality of growth are dependent on the dietary intake of protein and energy as well as inherent biologic and genetic differences among infants. The latter influences, although important, do not seem to obscure the effects of diet in a population of infants. Thus, it should be possible to determine the effects of the quality of early growth of LBW infants on a variety of short- and long-term outcomes. Such a study, conceivably, could answer the important question of whether early diet imprints subsequent intake and, hence, quality of growth. Concurrently, it should be possible to begin to assess the extent to which the inherent biologic and genetic mechanisms that seem to influence how an individual infant utilizes protein and energy for growth during the neonatal period remain functional as the infant matures. For example, does an infant who stores fat at a higher-than-predicted rate during the neonatal period continue to do so, and, hence, is this infant more likely to be an obese child, adolescent, or adult than the infant who stores fat at the predicted or at a less-than-predicted rate during the neonatal period?

\section{REFERENCES}

1. American Academy of Pediatrics, Committee on Nutrition 1985 Nutritional needs of low birth weight infants. Pediatrics 75:976-996

2. Putet G 1993 Energy. In: Tsang RC, Lucas A, Uauy R, Zlotkin S (eds) Nutritional Needs of the Preterm Infant, Scientific Basis and Practical Guidelines. Williams \& Wilkins, Baltimore, pp 15-28

3. Schulze KF, Stefanski M, Masterson J, Spinnazola R, Ramakrishnan R, Del RB, Heird WC 1987 Energy expenditure, energy balance and composition of weight gain in low birth weight infants fed diets of different protein and energy content. J Pediatr 110:753-759

4. Whyte RK, Haslam R, Vlainic C, Shannon S, Samulski K, Campbell D, Bayley HS, Sinclair JC 1983 Energy balance and nitrogen balance in growing lowbirth weight infants fed human milk or formula. Pediatr Res 17:891-898

5. Reichman B, Chessex P, Verellen G, Putet G, Smith JM, Heim T, Swyer PR
1983 Dietary composition and macronutrient storage in preterm infants. Pediatrics 72:322-328

6. Putet G, Senterre J, Rigo J, Salle B 1984 Nutrient balance, energy utilization, and composition of weight gain in very low birth weight infants fed pooled human milk or a preterm formula. J Pediatr 105:79-85

7. Whyte RK, Campbell D, Stanhope RN, Bayley HS, Sinclair JC 1986 Energy balance in low-birthweight infants fed formula of high or low medium-chain triglyceride content. J Pediatr 108:964-971

8. Roberts SB, Lucas A 1987 Energetic efficiency and nutrient accretion in preterm infants fed extremes of dietary intake. Clin Nutr 416:105-113

9. Fomon SJ 1967 Body composition of the male reference infant during the first year of life. Pediatrics 40:863-870

10. Kashyap S, Forsyth M, Zucker C, Ramakrishnan R, Dell RB, Heird WC 1986 Effects of varying protein and energy intakes on growth and metabolic response in low birth weight infants. J Pediatr 108:955-963

11. Kashyap S, Schulze KF, Forsyth M, Zucker C, Dell RB, Ramakrishnan R, Heird WC 1988 Growth, nutrient retention and metabolic response of low birth weight infants fed varying intakes of protein and energy. J Pediatr 113:713-721

12. Kashyap S, Schulze KF, Forsyth M, Dell RB, Ramakrishnan $R$, Heird WC 1990 Growth, nutrient retention and metabolic response of low birth weight infants fed supplemented and unsupplemented preterm human milk. Am J Clin Nutr 52:254-262

13. Kashyap S, Okamoto E, Kanaya S, Zucker C, Abildskov K, Dell RB, Heird WC 1987 Protein quality in feeding low birth weight infants: a comparison of whey-predominant $v s$. casein-predominant formulas. Pediatrics 79:748755

14. Heird WC, Kashyap S, Schulze KF, Ramakrishnan R, Zucker C, Dell RB 1987 Nutrient utilization and growth. In: Goldman A, Atkinson SA, Hanson LA (eds) Human Lactation 3. The Effects of Human Milk on the Recipient Infant. Plenum Press, New York, pp 9-21

15. Shelly HJ 1964 Carbohydrate reserves in the newborn infant. Br Med J [Clin Res] 1:273-275

16. Widdowson EM 1974 Changes in body proportion and composition during growth. In: Davis JA, Dobbing J (eds) Scientific Foundation of Pediatrics. Saunders, Philadelphia, pp 153-164

17. Food and Agricultural Organization of the United Nations Ad Hoc Committee 1973 Energy and protein requirements. FAO Nutritional Series No. 7, Rome. p 1024

18. Ziegler EE, O'Donnell AM, Nelson SE, Fomon SJ 1976 Body composition of the reference fetus. Growth 40:329-341

19. Munro HN 1964 General aspects of the regulation of protein metabolism by diet and by hormones. In: Munro HN, Allison JB (eds) Mammalian Protein Metabolism, Vol 1. Academic Press. New York, pp 381-481

20. Calloway DH, Spector H 1954 Nitrogen balance as related to calorie and protein intake in active young men. Am J Clin Nutr 2:405-412

21. Cotlove E, Trantham HNV, Bownman RL 1958 Instrument and method for automatic rapid accurate and sensitive titration of chlorides in biological samples. J Lab Clin Med 50:358-371

22. Baginski ES, Foa PO, Zak B 1967 Microdetermination of inorganic phosphate. phospholipids, and total phosphate in biologic materials. Clin Chem 13:326332

23. Miller DS. Payne PR 1959 A ballistic bomb calorimeter. Br J Nutr 13:501508

24. Kleiber M 1975 The Fire of Life: An Introduction to Animal Energetics. Krieger, New York, pp 104-130

25. Lusk G 1961 Basal metabolism standards. Scientific Tables, Ed 6. Documenta Geigy, Montreal, p 628

26. Schulze K, Kairam R, Stefanski M, Sciacca R, James LS 1981 Continuous measurement of minute ventilation and gaseous metabolism of newborn infants. J Appl Physiol 50:1098-1103

27. Bland JM, Altman DG 1986 Statistical methods for assessing agreement between two methods of clinical measurement. Lancet 2:307-310

28. Battaglia FC, Lubchenco LO 1967 A practical classification of newborn infants by weight and gestational age. J Pediatr 71:1659-1663

29. Mondino A, Bongiovanni G, Fumero S 1975 A new approach for obtaining total tryptophan recovery in plasma samples deproteinized with sulphosalicylic acid. J Chromatogr 104:297-302

30. Pittard WB, Geddes KM, Picone TA 1988 Cord blood amino acid concentrations from neonates of 23-41 weeks gestational age. JPEN 12:167-169

31. Munro HN, Naismith DJ 1953 Influence of energy intake on protein metabolism. Biochem J 54:191-197

32. Richardson DP, Waylar AH, Scrimshaw NS, Young VR 1979 Quantitative effect of an isoenergetic exchange of fat for carbohydrate on dietary protein utilization in healthy young men. Am J Clin Nutr 32:2217-2226

33. Campbell RG, Caperna TJ, Steele NC, Mitchell AD 1987 Effects of porcine pituitary growth hormone administration and energy intake on growth performance of pigs from 25:55 kg body weight. J Anim Sci 65(suppl 1):244(abstr)

34. Rother K, Zachmann M, Kempken B, Gruters A, Schnabel D, Allemand DL, Hausler G, Frisch H 1989 Effect of recombinant human growth hormone on urinary ${ }^{15} \mathrm{~N}$-nitrogen balance in girls with Turner syndrome as compared to children with growth hormone deficiency. Horm Res 32:166-169

35. Manson J McK. Wilmore DW 1986 Positive nitrogen balance with human growth hormone and hypocaloric intravenous feeding. Surgery 100:188-197 